УДК 579.64:579.852.11:664.8.03:633.15

\title{
TRENDS OF MICROBIOLOGICAL PROCESSES IN PRESERVED CORN ROLLED GRAIN UNDER THE INFLUENCE OF BACILLUS SUBTILIS
}

\author{
M. H. Perederii, N. O. Kravchenko, L. V. Bozhok, O. M. Dmytruk \\ Institute of Agricultural Microbiology and Agroindustrial Manufacture, NAAS; \\ e-mail: mashaperederii@ukr.net
}

Objective. To study the trends of microbiological processes, changes in the level of acidity and the ratio of accumulated organic acids in preserved corn rolled grain due to the influence of selected strains of Bacillus subtilis, promising for the creation of biological preservatives on their basis. Methods. Microbiological, zootechnical. Results. Grain processing with suspensions of the test strains of B. subtilis promotes the intensive development of epiphytic lactic acid bacteria in feed at day 15 of preservation, with subsequent gradual decrease at day 30 and 70 of the experiment. The number of lactic acid bacteria at day 14 after opening samples of preserved corn rolled grain is a tenfold higher than in the control variant (without the additional application of microorganisms). The dynamics of yeast growth in the feed due to the effect of the test strains of B. subtilis is characterized by their intensive development at day 15 with a gradual decrease in the number in all variants at day 30 and 70 of preservation. The number of moulds in the control variant exceeds the maximum allowable level (up to $5 \times 10^{4} \mathrm{CFU}$ per $1 \mathrm{~g}$ feed) and is $2 \times 10^{5}$ at day 7 and $6.2 \times 10^{5}$ at day 14 after opening and access of air to the thickness of the preserved mass. In experimental variants, the number of moulds is smaller compared with the control both in the process of preservation and after opening the feed. The optimum $\mathrm{pH}$ and the ratio of organic acids at day 14 after opening has been registered in the rolled grain treated with B. subtilis B1, B. subtilis B6y and B. subtilis 44-p. Conclusion. The use of selected B. subtilis strains to preserve moist corn rolled grain promotes the establishment of the optimum level of acidity of the feed and the ratio of organic acids, inhibition of the development of undesirable microorganisms.

Key words: Bacillus subtilis, corn rolled grain, biological preservatives, yeasts, moulds, preservation.

Introduction. The preparation of grain collected in the early stages of maturation at a moisture content of $35-40 \%$ is a promising, low-cost way of producing feed, since such a grain is an inexpensive source of nutrients, well fed and digested by animals [1-7]. However, the increased moisture content of raw materials creates optimal conditions for the development of moulds and putrefactive bacteria. Preventing loss during the storage of preserved rolled grain can be done using microbial preservatives. However, feed production in Ukraine is not fully provided with effective biological domestic preservatives. 
Analysis of the recent studies and publications. When selecting strains of microorganisms for the development of biopreservatives for moist rolled grain, it is important to take into account: their technological efficiency and safety; osmotic tolerance (ability to withstand increased osmotic pressure and reduced humidity); the ability to synthesize organic acids (primarily lactic acid), production of antibiotic and antifungal substances [8-13]. It is also important to assess the impact of the strains of microorganisms promising for production of biopreservatives on the trends of microbiological processes in the preserved rolled grain.

It is known that representatives of Bacillus subtilis possess high antagonistic and antifungal activity, on the basis of which both probiotics and biopreservatives are developed [14-16]. In addition to these properties, the mechanism of preservation action of B. subtilis lies in their ability to produce enzymes [17], which break down carbohydrates, which are further transformed into organic acids (primarily lactic acid) [18].

Objective. To study the dynamics of the development of microorganism populations in the preserved corn rolled grain under the influence of strains of Bacillus subtilis, promising for the creation of biological preservatives.

Materials and methods. The study of the influence of strains of aerobic bacilli on the dynamics of the development of microorganism populations in the preserved corn rolled grain was conducted in the Laboratory of Probiotics at the Institute of Agricultural Microbiology and Agroindustrial Manufacture of the National Academy of Agrarian Sciences of Ukraine.

Study objects were 4 strains of $B$. subtilis from the collection of microorganisms of the Laboratory of Probiotics: B1, B6y, B32, 44-p, possessing high enzymatic activity [17], show antagonistic and antifungal activity [18].

Stock bacterial cultures were obtained under the use of standard digest media - meat-peptone broth (MPB) and MPA for 24 hours at $37^{\circ} \mathrm{C} \pm 0.5^{\circ} \mathrm{C}$. Further cultivation of aerobic bacilli was carried out on a synthetic medium consisting of water-soluble starch, MPB, treacle, and salts of magnesium, potassium and ammonium for 24 hours at $37^{\circ} \mathrm{C} \pm 0.5^{\circ} \mathrm{C}$.

Preservation of corn grain with a moisture content of $30.2 \%$ was carried out under the laboratory conditions in $3 \mathrm{~L}$ polyethylene containers. The following variants were tested: 1 - without bacterial treatment (control); 2 - treatment with B. subtilis B1; 3 - B. subtilis B6y; 4 - B. subtilis B32; 5 B. subtilis 44-p. Suspensions of these strains were introduced at a rate of $8 \times 10^{9} \mathrm{CFU} / \mathrm{kg}$ raw material. Samples were stored at room temperature in a dark place.

Preliminary microbiological and zootechnical study of moist corn grain was performed before the bacterial processing of raw materials. 
Samples of corn grain to determine the total number of microorganisms, the amount of lactic acid bacteria, micromycetes, clostridia, the content of organic acids and $\mathrm{pH}$ were collected by conventional methods [19] at day 15, 30 and 70 of preservation, as well as after opening samples of preserved rolled grain at day 7 and 14 .

The number of microscopic fungi and yeast was determined on Sabouraud medium by surface inoculation, followed by cultivation for 3-4 days (7-8 days, if necessary) at $28^{\circ} \mathrm{C} \pm 0.5^{\circ} \mathrm{C}$. The number of clostridia was determined on the iron sulphate agar by the number of black colonies that grew up in the depths of the medium for 24 hours of cultivation at $37^{\circ} \mathrm{C} \pm 0.5^{\circ} \mathrm{C}$. The total number of microorganisms on the preserved rolled grain was determined on MPA with deep inoculation, followed by cultivation for 5-7 days at $37^{\circ} \mathrm{C} \pm 0.5^{\circ} \mathrm{C}$. The presence of lactic acid bacteria was determined on MRS and cabbage agar with chalk, counting the number of colonies in $2-7$ days of cultivation at $37^{\circ} \mathrm{C} \pm 0.5^{\circ} \mathrm{C}[20]$.

Determination of active acidity $(\mathrm{pH})$ was carried out by potentiometric measurement of the activity of hydrogen ions using pH-meter (pH-150 MI) [19].

The number of free and bound organic acids was determined by the Lepper-Flieg method [19].

The results obtained are statistically processed using the Microsoft Office application package and presented in the form of means and their errors $(\mathrm{M} \pm \mathrm{m})[21]$.

Results and discussion. Under conducting studies on the total number of microorganisms in the preserved moist corn rolled grain after treating strains of aerobic bacilli in three variants (B subtilis B1, B32, 44-p), the peak of their development was determined at day 15 of preservation, then it was gradually decreasing (Fig. 1) In general, in variants under treatment of grain with suspensions of aerobic bacilli, the total number of microorganisms reduced a tenfold compared with this parameter in the control at day 30 day and hundred fold - at day 70 of preservation.

Note: * - the day of preservation; ** - the day after the opening.

Fig. 1. Influence of B. subtilis on the dynamics of development of microorganisms (total number) in the preserved moist corn rolled grain.

The smallest parameters of the total number of microorganisms at day 14 after opening samples of the preserved corn rolled grain were found in variants of B. subtilis B1, B6y and B32 and amounted to $1.5 \times 10^{8}, 1.8 \times 10^{8}$ and $1.6 \times 10^{8} \mathrm{CFU} / \mathrm{g}$, respectively, versus $2.8 \times 10^{9} \mathrm{CFU} / \mathrm{g}$ in the control variant.

The number of epiphytic lactic acid bacteria (LAB) in the control variant at day 15 of preservation increased tenfold compared with this parameter in the raw material (from $1.0 \times 10^{8} \mathrm{CFU} / \mathrm{g}$ to $3.1 \times 10^{9}$ CFU/g) (Fig. 2). 
When treating grain with suspensions of the test strains of microorganisms, the maximum number of epiphytic lactic acid bacteria in the feed was registered at day 15 of preservation in the variant of B. subtilis B6y - their number increased to $1.5 \times 10^{10} \mathrm{CFU} / \mathrm{g}$ (in the control variant $-3.1 \times 10^{9} \mathrm{CFU} / \mathrm{g}$ ), and in the future began to decrease. In two other variants (B. subtilis B1 and B32), the number of lactic acid bacteria continued to increase till day 70 of preservation and was higher than the corresponding parameters in the control variant, and in the sample from B. subtilis B1, it exceeded the control values tenfold $\left(1.2 \times 10^{10} \mathrm{CFU} / \mathrm{g}\right.$ vs. $7.4 \times 10^{9} \mathrm{CFU} / \mathrm{g}$, respectively). At day 14 after opening samples of preserved corn rolled grain, the parameters of the number of lactic acid bacteria in experimental variants were tenfold higher than in the control.

Fig. 2 Influence of B. subtilis on the dynamics of development of epiphytic lactic acid bacteria in the preserved moist corn rolled grain.

The stability of feed to the process of aerobic deterioration depends on the number of yeasts in the preserved mass [22]. The dynamics of the number of yeasts under the influence of the test strains of aerobic bacteria indicates their rapid development at day 15 of preservation -1.25 to 2.96 -fold increase, compared with the initial raw material, and a gradual decrease in their number in all experimental variants at day 30 and 70 (Fig. 3) At the same time, in the control variant, the number of yeasts intensively increases (tenfold at day 70 of preservation) and continues to increase after the opening of the feed.

Fig. 3 Influence of B. subtilis on the dynamics of yeast development in the preserved moist corn rolled grain.

At day 7 after opening preserved corn rolled grain, yeast growth rates increase, most (tenfold) in two variants (B. subtilis B1 and B6y). The minimum number of yeasts at day 14 day after opening samples is registered in variants with B. subtilis B6y, B32 and 44-p $\left(1.0 \times 10^{4}, 1.4 \times 10^{4}\right.$ and $1.3 \times 10^{4}$ $\mathrm{CFU} / \mathrm{g}$, respectively), indicating greater resistance to aerobic deterioration of preserved corn rolled grain.

The development of moulds in the preserved mass leads not only to deterioration of feed but also to the accumulation of mycotoxins dangerous to the animal health, which makes the feed unsuitable for feeding $[22,23]$. The results of the study of the dynamics of the development of moulds in preserved moist corn rolled grain under the influence of strains of aerobic bacilli showed that their number in experimental variants up to day 30 of preservation is reduced and amounted to $1.0-2.5 \times 10^{3}$, and is virtually not detected $\left(0.12-0.22 \times 10^{3} \mathrm{CFU} / \mathrm{g}\right)$ at day 70 of preservation (Fig. 4). 
Fig. 4. Influence of B. subtilis on the dynamics of mould development in the preserved moist corn rolled grain.

At the same time, under access of air to the depth of preserved mass, when the feed is opened, the number of moulds increases, most of all in the control variant - 4-fold at day 7 and 12.4-fold at day 14 $\left(2 \times 10^{5}\right.$ and $6.2 \times 10^{5}$, respectively). In experimental variants, these parameters are shown within the ranges of acceptable contamination with microscopic fungi (the maximum allowable range - up to $5 \times 10^{4} \mathrm{CFU}$ per $1 \mathrm{~g}$ feed) [24] that is $0.1-2 \times 10^{4}$, suggesting better aerobic stability of the moist corn rolled grain under treatment with test strains of $B$. subtilis. The lowest number of moulds after opening was registered in the variants of B. subtilis $\mathrm{B} 1$ and B6y.

Butyric acid bacteria of the genus Clostridium, which produce butyric acid and contribute to the loss of energy up to $20 \%$, are undesirable in the process of silage [17; 18]. In the study of the number of butyric acid bacteria of the genus Clostridium in the preserved moist corn rolled grain only in some variants (from B. subtilis B6y, B32, 44-p), isolated colonies were detected at day 15 of preservation. At day 30 and 70, no growth of butyric acid bacteria was detected in any variant, which indicates the accumulation of a sufficient amount of lactic acid and a decrease in acidity to an optimal level. In addition, in the control variant, butyric acid bacteria were detected at day 15 of preservation and after the opening of the feed.

Study of the dynamics of reducing the level of acidity, accumulation of organic acids and their ration in the preserved mass is important to evaluate the factors affecting the efficiency of fermentation processes and maintenance of preserved corn rolled grain, along with microbiological parameters.

In the course of study, it was established that in the control variant (without treatment of raw materials by suspensions of microorganisms) the ratio of organic acids in the process of preservation varied as follows: at day 15 the proportion of lactic acid in the acid content was more than $83 \%$, at day 70 - more than $76 \%$, and after opening at day 14 - only $10 \%$ (Table 1 ). At the same time, the proportion of butyric acid in this variant at day 14 after opening was over $89 \%$, indicating that the preserved mass created favourable conditions for the rapid development of butyric acid bacteria.

Table 1. Accumulation of organic acids in preserved moist corn rolled grain under the influence of B. subtilis strains, $\mathrm{M} \pm \mathrm{m}$

\begin{tabular}{|c|c|c|c|c|c|c|}
\hline \multirow{2}{*}{\multicolumn{2}{|c|}{ Organic acids }} & \multirow{3}{*}{$\begin{array}{l}\text { Control } \\
83.1 \pm 0.1\end{array}$} & \multicolumn{4}{|c|}{ B. subtilis strains } \\
\hline & & & B1 & B6y & B32 & $44-p$ \\
\hline \multirow{3}{*}{$\cdot \stackrel{0}{0}$} & Day 15 of preservation & & $81.7 \pm 0.3$ & $84.9 \pm 0.1$ & $79.4 \pm 0.2$ & $80.5 \pm 0.2$ \\
\hline & Day 30 of preservation & $84.3 \pm 0.3$ & $83.9 \pm 0.1$ & $85.8 \pm 0.2$ & $85.4 \pm 0.1$ & $81.7 \pm 0.4$ \\
\hline & Day 70 of preservation & $76.5 \pm 0.2$ & $95.6 \pm 0.3$ & $86.3 \pm 0.2$ & $91.7 \pm 0.1$ & $86.0 \pm 0.3$ \\
\hline
\end{tabular}




\begin{tabular}{|c|c|c|c|c|c|c|}
\hline & Day 7 after opening & $70.6 \pm 0.3$ & $80.9 \pm 0.2$ & $78.7 \pm 0.1$ & $80.4 \pm 0.3$ & $77.1 \pm 0.1$ \\
\hline & Day 14 after opening & $10.2 \pm 0.2$ & $78.5 \pm 0.1$ & $76.3 \pm 0.1$ & $79.7 \pm 0.1$ & $72.0 \pm 0.2$ \\
\hline \multirow{5}{*}{ 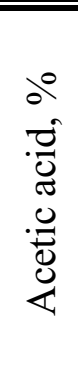 } & Day 15 of preservation & $16.9 \pm 0.1$ & $18.3 \pm 0.1$ & $15.1 \pm 0.1$ & $20.6 \pm 0.3$ & $19.5 \pm 0.2$ \\
\hline & Day 30 of preservation & $15.1 \pm 0.1$ & $16.1 \pm 0.3$ & $14.2 \pm 0.1$ & $14.6 \pm 0.1$ & $18.3 \pm 0.3$ \\
\hline & Day 70 of preservation & $23.5 \pm 0.1$ & $4.4 \pm 0.1$ & $13.7 \pm 0.2$ & $8.3 \pm 0.1$ & $14.0 \pm 0.1$ \\
\hline & Day 7 after opening & $29.4 \pm 0.1$ & $19.1 \pm 0.1$ & $21.3 \pm 0.3$ & $19.6 \pm 0.2$ & $22.9 \pm 0.1$ \\
\hline & Day 14 after opening & $0.5 \pm 0.1$ & $21.5 \pm 0.3$ & $23.7 \pm 0.2$ & $20.3 \pm 0.1$ & $28.0 \pm 0.3$ \\
\hline \multirow{5}{*}{ 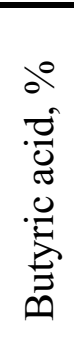 } & Day 15 of preservation & $\overline{0}$ & $\overline{0}$ & $\overline{0}$ & 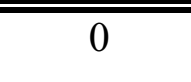 & 0 \\
\hline & Day 30 of preservation & $0.6 \pm 0.01$ & 0 & 0 & 0 & 0 \\
\hline & Day 70 of preservation & 0 & 0 & 0 & 0 & 0 \\
\hline & Day 7 after opening & 0 & 0 & 0 & 0 & 0 \\
\hline & Day 14 after opening & $89.3 \pm 0.2$ & 0 & 0 & 0 & 0 \\
\hline
\end{tabular}

Note. Probability level of difference with control is $\mathrm{P} \leq 0.05$.

However, in experimental variants (with the treatment of grain with suspensions of aerobic bacilli strains), the proportion of lactic acid at day 14 after the opening of the feed was an average of $76.6 \%$ in all variants in the absence of butyric acid. It should be noted that the acidity of the feed (Fig. 5) in the preservation process in the experimental variants was significantly lower in relation to the control and ranged from $\mathrm{pH} 3.5$ to $\mathrm{pH} 3.6$ versus $\mathrm{pH} 5.6$ in the control at day 15, and $\mathrm{pH} 3.6$ to $\mathrm{pH} 4.1$ versus $\mathrm{pH} 5.3$ in the control at day 70 of preservation.

Fig. 5. Influence of B. subtilis on the acidity level in the preserved moist corn rolled grain.

Thus, the positive effect of Bacillus subtilis on the trends of microbiological processes in preserved corn rolled grain has been established. The action of the test strains of bacteria promotes the intensive development of lactic acid bacteria, inhibits growth and development of micromycetes. Preservation of moist corn rolled grain without supplementation of bacilli does not ensures stability of microbiological parameters of the feed after its opening (there is the development of yeasts, moulds, and butyric acid bacteria), which leads to formation of moulds and putrefaction. Application of the test strains of aerobic bacillus to preserve the moist corn rolled grain provides the establishment of the optimum level of acidity of the feed, the desired ratio of organic acids.

Conclusion. Optimal microbiological parameters, level of acidity and the ratio of organic acids are registered in the variant of feed under application of B. subtilis B1. The above bacterial strain is promising for creation of biopreservatives for moist corn rolled grain. 
1. Виробництво, зберігання і використання кормів / За ред. Петриченка В. Ф. Вінниця : Діло, 2005. 472 с.

2. Gharechahi J., Kharazian Z. A., Sarikhan S., Jouzani G. S., Aghdasi M., Salekdeh G. H. The dynamics of the bacterial communities developed in maize silage. Microb Biotechnol. 2017. Vol. 10, Iss. 6. P. 1663-1676. https://doi.org/10.1111/1751-7915.12751

3. Gunn P. J., Buckmaster D. R., Lemenager R. P., Van Emon M. L., Claeys M. C., Lake S. L. Preservation characteristics of modified wet distillers grains with solubles stored with marginal-quality feedstuffs in laboratory-scale mini silos. Prof. Anim. Sci. 2013. Vol. 29, Iss. 6. P. 671676. https://doi.org/10.15232/S1080-7446(15)30299-0

4. Голохвастова С. И. Консервирование плющеного зерна - энергосберегающая технология. Животноводство России. 2000. № 4. С. 23-24.

5. Brüning D., Gerlach K., Weiß K., Südekum K.-H. Effect of compaction, delayed sealing and aerobic exposure on maize silage quality and on formation of volatile organic compounds. Grass and Forage Science. 2018. Vol. 73, Iss. 1. P. 53-66. https://doi.org/10.1111/gfs.12288

6. Косолапова Е. В. Анализ технологических приемов заготовки и хранения консервированого плющеного зерна. Вестник НГИЭИ. 2014. № 4 (35). С. 71-77.

7. Hymøller L., Hellwing A. L. F., Lund P., Weisbjerg M. R. Milk production is unaffected by replacing barley or sodium hydroxide wheat with maize cob silage in rations for dairy cows. Animal. 2014. Vol. 8, Iss. 5. P. 738-747. https://doi.org/10.1017/S1751731114000329

8. Суслова М. А. Влияние биологического препарата на микробиологические показатели и химический состав плющеного зерна кукурузы. Известия Оренбургского гос. Аграрного университета. 2012. № 34-1, Т. 2. С. 38-40.

9. Kleinschmit D. H., Schmidt R. J., Kung L. Jr. The effects of various antifungal additives on the fermentation and aerobic stability of corn silage. Journal of Dairy Science. 2005. Vol. 88, Iss. 6. P. 2130-2139. http://doi.org/10.3168/jds.S0022-0302(05)72889-7

10. Muck R. E. A lactic acid bacteria strain to improve aerobics stability of silages. Research Summaries. Madison: U. S. Dairy Forage Res. Center. 1996. P. 46-47.

11. Driehuis F., Elferink S. J., Oude W. H., Spolestra S. F. Anaerobic lactic acid degradation during ensilage of whole crop maize inoculated with Lactobacillus buchneri inhibits yeast growth and improves aerobic stability. J. Appl. Microbiol. 1999. Vol. 87, Iss. 4. P. 583-594. https://doi.org/10.1046/j.1365-2672.1999.00856.x

12. Queiroz O. C. M., Adesogan A. T., Arriola K. G., Queiroz M. F. S. Effect of a dualpurpose inoculant on the quality and nutrient losses from corn silage produced in farm-scale silos. Journal of Dairy Science. 2012. Vol. 95, Iss. 6. P. 3354-3362. https://doi.org/10.3168/jds.2011-5207 
13. Rodríguez A. A., Acosta Y., Rivera V., Randel P. F. Effect of a microbial inoculant on fermentation characteristics, aerobic stability, intake, and digestibility of corn silage by rams. Revista Colombiana de Ciencias Pecuarias, 2016. Vol. 29, № 2. P. 108-118. https://doi.org/10.17533/udea.rccp.v29n2a04

14. Кравченко Н. О., Чумаченко С. П., Передерій М. Г. Консервуюча здатність Bacillus subtilis при заготівлі плющенного вологого зерна кукурудзи. Сільськогосподарська мікробіологія. 2017. Вип. 25. С. 57-62.

15. Победнов Ю. А., Мамаев А. А. Эффективность применения бактерий вида Bacillus subtilis при силосовании и сенажировании трав. Ветеринарная патология. 2005. № 1. С. 90-96

16. Кравченко Н. О., Агеєв В. О., Божок Л. В., Чумаченко С. П., Дмитрук О. М. Консервування зернобобових кормових культур підвищеної вологості за використання бактеріального препарату БПС-Л. Науково-технічний бюлетень Інституту біології тварин i Державного науково-дослідного контрольного інституту ветпрепаратів та кормових добавок. 2012. Вип. 13, № 3-4. С. 202-206.

17. Передерій М. Г. Скринінг штамів мікроорганізмів за здатністю до біосинтезу гідролітичних ферментів. Мікробіологія в сучасному сільськогосподарському виробництві: матеріали XIII наукової конференції молодих вчених (м. Чернігів, 24-25 жовтня). Чернігів, 2018. C. $68-71$.

18. Кравченко Н. О., Передерій М. Г. Антагоністична активність штамів бактерій Bacillus subtilis, перспективних для створення консервантів вологого зерна плющеної кукурудзи. Сільськогосподарська мікробіологія. 2017. Вип. 26. С. 49-54.

19. Петухова Е. А., Бессарабова Р. Ф., Халенева Л. Д., Антонова О. А. Зоотехнический анализ кормов. М. : Агропромиздат, 1989. 239с.

20. Соляник Т. В., Гласкович М. А. Микробиология. Микробиология кормов животного и растительного происхождения. Горки : БГСХА, 2014. 76 с.

21. Коросов А. В. Горбач В. В. Компьютерная обработка биологических данных. Петрозаводск : ПетрГУ, 2016. 96 с

22. Надточаев Н. Ф., Абраскова С. В. Готовим концентрированные корма из кукурузы. Научно-практический центр НАН Беларуси по земледелию. 2009. Режим доступу: http://mshp.gov.by/arekomendacii/zs/2009/110809/rekomen110809.htm.

23. Оноприенко Н. А., Мандрыкина Н. А., Оноприенко В. В. Приготовление сенажа, кукурузного силоса и консервирование плющеного зерна кукурузы. Рекомендации производству. СКНИИЖ. Краснодар, 2012. 36 с.

24. Наказ Міністерства аграрної політики та продовольства України 19.03.2012 № 131 (у редакції наказу Міністерства аграрної політики та продовольства України від 11.10.2017 № 550) 
Про затвердження Переліку максимально допустимих рівнів небажаних речовин у кормах та кормовій сировині для тварин (Із змінами, внесеними згідно 3 Наказом Міністерства економічного розвитку і торгівлі N 550 від 11.10.2017). Офіціийний вісник України. 2012, № 29 (23 квітня). 86 с. Режим доступу: http://zakon.rada.gov.ua/laws/show/z0503-12/print

\section{REFERENCES}

1. Petrychenko, V.F. (Ed.). (2005). Vyrobnyctvo, zberigannja i vykorystannja kormiv [Production, storage and use of feed]. Vinnycja: Dilo [in Ukrainian].

2. Gharechahi, J., Kharazian, Z. A., Sarikhan, S., Jouzani, G. S., Aghdasi, M., \& Salekdeh, G. H. (2017). The dynamics of the bacterial communities developed in maize silage. Microb Biotechnol, 10(6), 1663-1676. https://doi.org/10.1111/1751-7915.12751

3. Gunn, P. J., Buckmaster, D. R., Lemenager, R. P., Van Emon, M. L., Claeys, M. C., \& Lake S. L. (2013). Preservation characteristics of modified wet distillers grains with solubles stored with marginal-quality feedstuffs in laboratory-scale mini silos. Prof. Anim. Sci, 29(6), 671-676. https://doi.org/10.15232/S1080-7446(15)30299-0

4. Golohvastova, S. I. (2000). Konservirovanie pljushhenogo zerna jenergosberegajushhaja tehnologija [Rolled Grain Canning - Energy Saving Technology]. Zhivotnovodstvo Rossii, 4, 23-24 [in Russian].

5. Brüning, D., Gerlach, K., Weiss, K., \& Südekum, K.-H. (2017). Effect of compaction, delayed sealing and aerobic exposure on maize silage quality and on formation of volatile organic compounds. Grass and Forage Science, 73(1), 53-66. https://doi.org/10.1111/gfs.12288

6. Kosolapova, E. V. (2014). Analiz tehnologicheskih priemov zagotovki i hranenija konservirovanogo pljushhenogo zerna [Analysis of technological methods of harvesting and storage of canned rolled grain]. Vestnik NGIJeI - Herald NGIEI , 4(35), 71-77 [in Russian].

7. Hymøller, L., Hellwing, A. L. F., Lund, P., \& Weisbjerg, M. R. (2014). Milk production is unaffected by replacing barley or sodium hydroxide wheat with maize cob silage in rations for dairy cows. Animal, 8(5), 738-747. https://doi.org/10.1017/S1751731114000329

8. Suslova, M. A. (2012). Vlijanie biologicheskogo preparata na mikrobiologicheskie pokazateli i himicheskij sostav pljushhenogo zerna kukuruzy [Effect of the biological preparation on microbiological indices and chemical composition of flattened corn grain]. Izvestija Orenburgskogo gos. Agrarnogo universiteta - Izvestia Orenburg State Agrian University, 2(1), 38-40 [in Russian].

9. Kleinschmit, D. H., Schmidt, R. J., \& Kung, Jr. L. (2005). The effects of various antifungal additives on the fermentation and aerobic stability of corn silage. Journal of Dairy Science, 88 (6), 2130-2139. https://doi.org/10.3168/jds.S0022-0302(05)72889-7

10. Muck, R. E. (1996). A lactic acid bacteria strain to improve aerobics stability of silages. Research Summaries (pp. 42-43). U.S. Dairy Forage Res. Center. Madison, WI. 
11. Driehuis, F., Oude Elferink, S. J. W. H., \& Spolestra, S. F. (1999). Anaerobic lactic acid degradation during ensilage of whole crop maize inoculated with Lactobacillus buchneri inhibits yeast growth and improves aerobic stability. J. Appl. Microbiol., 87(4), 583-594. https://doi.org/10.1046/j.1365-2672.1999.00856.x

12. Queiroz, O. C. M., Adesogan, A. T., Arriola, K. G., \& Queiroz, M. F. S. (2012). Effect of a dual-purpose inoculant on the quality and nutrient losses from corn silage produced in farm-scale silos. Journal of Dairy Science, 95(6), 3354-3362. https://doi.org/10.3168/jds.2011-5207

13. Rodríguez, A. A., Acosta, Y., Rivera, V., \& Randel, P. F. (2016). Effect of a microbial inoculant on fermentation characteristics, aerobic stability, intake, and digestibility of corn silage by rams. $\begin{array}{lllll}\text { Revista Colombiana de } & \text { Ciencias } & \text { Pecuarias, } & \text { 29(2). } & 118 .\end{array}$ https://doi.org/10.17533/udea.rccp.v29n2a04

14. Kravchenko, N. O, Chumachenko, S. P., \& Perederij, M. G. (2017). Konservujucha zdatnist' Bacillus subtilis pry zagotivli pljushhennogo vologogo zerna kukurudzy [Preserving ability of Bacillus subtilis during gathering of flattened moist corn grain]. Silskogospodarska mikrobiologia, 25, 57-62 [in Ukrainian].

15. Pobednov, Ju. A., \& Mamaev, A. A. (2005). Jeffektivnost' primenenija bakterij vida Bacillus subtilis pri silosovanii i senazhirovanii travu. [The effectiveness of the use of bacteria of the species Bacillus subtilis in ensiling and grass haying]. Veterinarnaja patologija - Veterinary Pathology, 1, 90-96 [in Russian].

16. Kravchenko, N. O., Agejev, V. O., Bozhok, L. V., Chumachenko, S. P., \& Dmytruk, O. M. (2012). Konservuvannja zernobobovyh kormovyh kul'tur pidvyshhenoi' vologosti za vykorystannja bakterial'nogo preparatu BPS-L [Preservation of leguminous fodder crops with high moisture content by the use of bacterial preparation BPS-1]. Nauk.-tehn. bjul. Instytutu biologii' tvaryn $i$ Derzhavnogo naukovo-doslidnogo kontrol'nogo instytutu vetpreparativ ta kormovyh dobavok, 13(3-4), 202-206 [in Ukrainian].

17. Perederij, M. G. (2018, October). Skryning shtamiv mikroorganizmiv za zdatnistju do biosyntezu gidrolitychnyh fermentiv [Screening of strains of microorganisms on the ability to biosynthesis of hydrolytic enzymes]. Proceedings of the XIII Scientific Conference of young scientists Microbiology in modern agricultural production (pp. 68-71), Chernigiv [in Ukrainian].

18. Kravchenko, N. O., Perederij, M. G. (2017). Antagonistychna aktyvnist' shtamiv bakterij Bacillus subtilis, perspektyvnyh dlja stvorennja konservantiv vologogo zerna pljushhenoi' kukurudzy [Antagonistic activity of Bacillus subtilis strains, perspective components for creation of rolled high-moisture corn preservatives]. Silskogospodarska mikrobiologia, 26, 49-54 [in Ukrainian].

19. Petuhova, E. A., Bessarabova, R. F, Haleneva, L. D., Antonova, O. A. (1989). Zootehnycheskyj analyz kormov [Zootechnical analysis of feeds]. Moskva : Agropromyzdat [in Russian]. 
20. Soljanyk, T. V., Glaskovych, M. A. (2014). Mykrobyologyja. Mykrobyologyja kormov zhyvotnogo y rastytel'nogo proyshozhdenyja [Microbiology. Microbiology of animal and plant feed]. Gorky : BGSHA [in Russian].

21. Korosov, A. V., Gorbach, V.V. (2016). Komp'juternaja obrabotka byologycheskyh dannjah [Computer processing of biological data]. Petrozavodsk : PetrGU [in Russian].

22. Nadtochaev, N. F., Abraskova., S. V. (2009). Gotovim koncentrirovannye korma iz kukuruzy [Prepare concentrated feed from corn]. Nauchno-prakticheskij centr NAN Belarusi po zemledeliju.

Retrieved from: https://www.mshp.gov.by/arekomendacii/zs/2009/110809/rekomen110809.htm [in Russian].

23. Onoprienko, N. A., Mandrykina, N. A., Onoprienko, V. V. (2012). Prigotovlenie senazha, kukuruznogo silosa i konservirovanie pljushhenogo zerna kukuruzy [Preparation of haylage, corn silage and canning of flattened corn]. SKNIIZh. Krasnodar [in Russian].

24. Nakaz Ministerstva agrarnoi' polityky ta prodovol'stva Ukrai'ny 19.03.2012 № 131 Pro zatverdzhennja Pereliku maksymal'no dopustymyh rivniv nebazhanyh rechovyn u kormah ta kormovij syrovyni dlja tvaryn [Order of the Ministry of Agrarian Policy and Food of Ukraine of 19.03.2012 № 131 On Approval of the List of Maximum Permissible Levels of Unwanted Substances in Forages and Forage For Animals]. (2012, 23 April). Retrieved from https://zakon.rada.gov.ua/laws/show/z0503-12/print [in Ukrainian]. 


\title{
СПРЯМОВАНІСТЬ МІКРОБІОЛОГІЧНИХ ПРОЦЕСІВ У КОНСЕРВОВАНОМУ ПЛЮЩЕНОМУ ЗЕРНІ КУКУРУДЗИ ЗА ВПЛИВУ БАКТЕРІЙ ВАCILLUS SUBTILIS
}

\author{
М.Г. Передерій, Н.О. Кравченко, Л.В. Божок, О.М. Дмитрук
}

Інститут сільськогосподарської мікробіології та агропромислового виробництва НААН, вул. Шевченка,97; м. Чернігів, 14035, Україна; e-mail: mashaperederii@ukr.net

Мета. Дослідити спрямованість мікробіологічних процесів, зміни рівня кислотності та співвідношення накопичених органічних кислот у консервованому плющеному зерні кукурудзи за впливу селекціонованих штамів Bacillus subtilis, перспективних для створення на їх основі біологічних консервантів. Методи. Мікробіологічні, зоотехнічні. Результати. Обробка зерна суспензіями досліджуваних штамів B. subtilis сприяе інтенсивному розвитку епіфітних молочнокислих бактерій у кормі на 15 добу консервування 3 подальшим поступовим зниженням на тридияту та семидесяту добу експерименту. Чисельність молочнокислих бактерій на 14 добу після відкриття зразків консервованого плющеного зерна кукурудзи на порядок вища, ніж у контрольному варіанті (без додаткового застосування мікроорганізмів). Динаміка росту дріжджів у кормі за впливу досліджуваних итамів B. subtilis характеризується їх інтенсивним розвитком на 15 добу з поступовим зниженням чисельності в усіх варіантах на 30 та 70 добу консервування. Чисельність плісеневих грибів у контрольному варіанті перевищує максимально допустимий рівень (до $5 \times 10^{4}$ КУО в 1 г корму) та становить $2 \times 10^{5}$ на 7 добу і $6,2 \times 10^{5}$ на 14 добу після відкриття та доступу повітря у товщу консервованої маси. У дослідних варіантах чисельність плісеневих грибів $\epsilon$ меншою порівняно з контролем як у процесі консервування так і після відкриття корму. Оптимальні рівень рН та співвідношення органічних кислот на 14 добу після відкриття відмічено у плющеному зерні, обробленому B. subtilis B1, B. subtilis B6y ma B. subtilis 44-p. Висновки. Застосування селекиіонованих штамів B. subtilis для консервування плющеного вологого зерна кукурудзи сприяє встановленню оптимального рівня кислотності корму та співвідношення органічних кислот, пригніченню розвитку небажаних мікроорганізмів.

Ключові слова: Bacillus subtilis, плющене зерно кукурудзи, біологічні консерванти, дріжджі, плісеневі гриби, консервування. 